\title{
Envejecimiento acelerado sobre la calidad de semillas de maíz para producir germinados para forraje alternativo*
}

\author{
Accelerated aging on the quality of maize seeds for \\ alternative sprouted fodder production
}

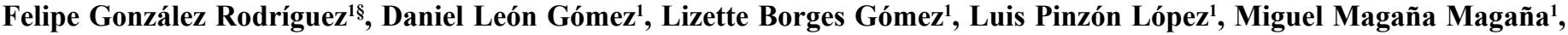
Roberto Sangines García ${ }^{1}$ y Miguel Urrestarazu Gavilán ${ }^{2}$

1'División de Estudios de Posgrado- Instituto Tecnológico de Conkal. km 16.3 antigua carretera Mérida-Motul, Conkal, C. P. 97345 Yucatán, México. (daniel5366@ hotmail.com;lizette_borges@hotmail.com;1pinlo@yahoo.com.mx;mmagana@itaconkal.edu.mx; rsangines@itaconkal.edu.mx)..2Departamento de Producción VegetalUniversidad de Almería. 04120 Almería, España. (mgavilan@ual.es). ^Autor para correspondencia: delagro2006@yahoo.com.mx.
\end{abstract}

\section{Resumen}

La semilla de maíz de buena calidad es insumo estratégico para producir germinados como forraje alternativo para alimentación animal sobre todo en época de sequía y el almacenamiento prolongado conduce a pérdidas de germinabilidad y vigor en función del genotipo y ambiente. El estudio se desarrolló en el Instituto Tecnológico de Conkal en julio de 2011, el envejecimiento acelerado se aplicó a tres materiales de maíz (País tuxpeño, X'nuuknal y Sinaloa) durante 24 y $48 \mathrm{ha} 45^{\circ} \mathrm{C}$ asumiendo 85 a $100 \%$ de humedad relativa con el objetivo de evaluar su efecto en germinación y desarrollo de plántulas de maíz, en invernadero la siembra fue en bandejas de plástico con estiércol de bovino como sustrato. Las variables evaluadas: peso inicial semillas, número medio de días a germinación total, porcentaje de germinación, altura de planta, peso fresco y seco total, área foliar total, peso fresco y seco de la raíz y vástago y la relación vástago: raíz. El diseño experimental fue bloques completos al azar con arreglo factorial $3 \times 3$ con $(n=5)$ y comparación de medias Tukey $(p<0.05)$. Los resultados mostraron diferencias significativas entre materiales de maíz en todas las variables mientras que el efecto de tiempos de envejecimiento acelerado y la interacción de ambos únicamente mostraron diferencias significativas en

\section{Abstract}

The maize seed of good quality is strategic input to produce sprouts as an alternative fodder for animal feed especially in times of drought and prolonged storage, leading to loss of germinability and vigor according to genotype and environment. The study was conducted at the Conkal Institute of Technology in July 2011, accelerated aging was applied to three maize cultivars (País Tuxpeño, X'nuuknal and Sinaloa) for 24 and $48 \mathrm{~h}$ at $45{ }^{\circ} \mathrm{C}$ assuming 85 to $100 \%$ relative humidity in order to evaluate its effect on maize seedling germination and development in greenhouse, planting was in plastic trays with bovine manure as substrate. The evaluated variables: initial seed weight, average number of days to total germination, germination percentage, plant height, total fresh and dry weight, total leaf area, fresh and dry weight of root and shoot and shoot: root ratio. The experimental design was randomized complete blocks with $3 \times 3$ factorial arrangement with $(n=5)$ and Tukey means comparison $(p<0.05)$. The results showed significant differences between maize cultivars in all variables whereas the effect of accelerated aging times and the interaction of both showed significant differences only in germination percentage. ThePaís Tuxpeño maize was more favorable to produce green forage for its viability and resistance to deterioration.

\footnotetext{
* Recibido: marzo de 2014

Aceptado: abril de 2014
} 
porcentaje de germinación. El maíz País Tuxpeño por su viabilidad y resistencia al deterioro resultó el más favorable para producir forraje verde.

Palabras claves: deterioro, forraje verde, sustrato, viabilidad.

La producción del germinado de maíz es importante fuente de forraje alternativo para alimentación animal sobre todo en época de sequía y la calidad de semillas es estratégica para incrementar el peso fresco total. La calidad de semillas implica la integridad de estructuras y procesos fisiológicos para conservar la viabilidad(Vitoria, 2007). Los indicadores de ésta son: la germinación y el vigor, que dependen del genotipo y del manejo en la producción y post-cosecha (Flores, 2004; Salazar et al., 2006).

El envejecimiento acelerado deteriora la semilla y es igual al que ocurre naturalmente, es la prueba de vigor más aplicada a semillas comerciales (Vashisth, 2009; Durán et al., 2011) por su exposición a temperaturas y humedad altos (Barros y Filho, 2003) merman su capacidad germinativa, el crecimiento inicial de plántulas, la tolerancia a condiciones adversas y no ocurre uniformemente en semillas, aún en un mismo lote (McDonald, 1999). El propósito del presente estudio fue evaluar el efecto de envejecimiento acelerado sobre la viabilidad, desarrollo y crecimiento de plántulas de tres materiales de maíz para producir germinados como forraje alternativo.

El experimento se realizó en el Instituto Tecnológico de Conkal, Yucatán en julio de 2011. Se utilizaron tres materiales demaíz producidos y disponibles en Yucatán, dos tipos de raza Tuxpeño, el País Tuxpeño(PT) y X'nuuknal(X) cosechados y almacenados en trojes rústicos a temperatura ambiente $28^{\circ} \mathrm{C}$ y humedad relativa $85 \%$ en julio de 2011 y el tercer material de maíz se trae de Sinaloa (S) en sacos de rafia a temperatura ambiente $28^{\circ} \mathrm{C}$; en la práctica los tres materiales de maíz se utilizan en producción de germinados para forraje fresco.

El contenido de humedad del País Tuxpeño 11\%, Xnuuknal $10.39 \%$ y Sinaloa $10 \%$. El envejecimiento acelerado fue inducido a lotes de 25 semillas, para tal fin se envolvieron con tela de pabellón sujetos con un hilo de algodón a $1 \mathrm{~cm}$ de separación del nivel de agua destilada 2 L agregada al vaso de precipitado de 4 L sellado con papel parafilm y aluminio, asumiendo una humedad relativa de 85 a $100 \%$, se aplicaron tres tratamientos para el deterioro de semillas: 1) tiempo cero y temperatura ambiente de $26^{\circ} \mathrm{C}$ como testigo;2) tiempo de
Keywords: deterioration, green fodder, substrate, viability.

The production of sprouted maize is an important alternative forage source for animal feed especially in times of drought, and seed quality is strategic to increase the total fresh weight. Seed quality involves the integrity of physiological structures and processes for preserving viability (Vitoria, 2007). Indicators of this are: germination and vigor, depending on the genotype and production and post-harvest management. (Flores, 2004; Salazar et al., 2006).

Accelerated aging deteriorates the seed and equals the natural process, it is the vigor test most applied to commercial seed (Vashisth, 2009; Durán et al., 2011) by exposure to high temperatures and humidity (Barros and Filho, 2003) undermine their germination capacity, seedling early growth, tolerance to adverse conditions and does not occur uniformly in seeds, even in the same batch (McDonald, 1999). The purpose of this study was to evaluate the effect of accelerated aging on viability, development and growth of seedlings of three maize materials to produce sprouts as alternative fodder.

The experiment was carried out at the Conkal Institute of Technology, Yucatán in July 2011. Three maize materials produced and available in Yucatán were used, two types of Tuxpeño race, the País Tuxpeño (PT) and X'nuuknal $(\mathrm{X})$ harvested and stored in rustic barns at $28{ }^{\circ} \mathrm{C}$ room temperature and $85 \%$ relative humidity in July 2011 and the third maize material is brought from Sinaloa (S) in raffia bags at $28{ }^{\circ} \mathrm{C}$ room temperature, in practice the three maize materials are used in sprouts production for fresh fodder.

The moisture content in País Tuxpeño is $11 \%$, Xnuuknal $10.39 \%$ and Sinaloa $10 \%$. Accelerated aging was induced in lots of 25 seeds, for this purpose they were wrapped with tent cloth held with a cotton thread $1 \mathrm{~cm}$ from the level of distilled water, $2 \mathrm{~L}$ added to the $4 \mathrm{~L}$ beaker, sealed with parafilm paper and aluminum assuming 85 to $100 \%$ relative humidity, three treatments were applied for seed deterioration: 1) zero time and ambient temperature of 26 ${ }^{\circ} \mathrm{C}$ as a check ; 2) time of $24 \mathrm{~h}$ at a constant temperature of $45^{\circ} \mathrm{C}$; and 3) time of $48 \mathrm{~h}$ at constant temperature of $45^{\circ} \mathrm{C}$ (Salazar et al., 2006, Villaroel and Méndez-Natera 2007). A randomized block design was used with $3 \times 3$ factorial arrangement with $(n=5)$, the first factor was time 0,24 and $48 \mathrm{~h}$ and the second factor was three maize materials País Tuxpeño, X'nuuknaal and Sinaloa. 
$24 \mathrm{~h}$ a una temperatura constante $45^{\circ} \mathrm{C}$; y 3$)$ tiempo de $48 \mathrm{~h}$ a temperatura constante $45^{\circ} \mathrm{C}$ (Salazar et al., 2006, Villaroel y Méndez-Natera 2007). Se utilizó un diseño de bloques al azar con arreglo factorial $3 \times 3$ con $(n=5)$, el primer factor fue tiempo $0,24 \mathrm{y} 48 \mathrm{~h}$ y el segundo factor tres materiales de maíz País Tuxpeño, X’nuuknaal y Sinaloa.

La germinación, el crecimiento y desarrollo de plántulas de maíz se realizó en invernadero, las semillas de maíz envejecidas aceleradamente se colocaron en bandejas de plástico $0.242 \mathrm{~m}^{2}$ con estiércol de bovino como sustrato el cual contenía 2.24, 0.31, 0.47\% de N, P, K respectivamente. Las variables de germinación y desarrollo fueron: peso inicial de semilla (PIS), porcentaje de germinación (PG), número medio de días a germinación total (NMDG), altura de plántula (AP), peso fresco total (PFT), peso seco total (PST), área foliar total (AFT), peso fresco y seco de raíz y vástago (PFR, PFV, PSR y PSV) respectivamente y relación vástago:raíz (V: R). Los análisis de variables evaluadas y la prueba de medias de Tukey $(p<0.05)$ se realizaron con el programa Statistica Six Sigma.

El peso inicial de maíz País Tuxpeño, X'nuuknal y Sinaloa presentó diferencias significativas $(p<0.05)$. Elvalor más alto de 8.5 g seapreció en el Sinaloa mientras que en País Tuxpeño y X'nuuknal mostraron valores menores 7.1 y $6.9 \mathrm{~g}$ Figura 1.

El análisis de variables por efecto de la aplicación de envejecimiento acelerado de acuerdo al factor materiales de maíz presentó diferencias significativas mientras que el efecto de tiempos de envejecimiento acelerado y la interacción mostraron diferencias significativas únicamente en el porcentaje de germinación, ésta tendencia la ha reportado Salazar et al. (2006) quienes informaron que la calidad de semilla de maíz está relacionada directamente con el aumento en tiempo de envejecimiento acelerado, disminuyendo el porcentaje de germinación de éstas.

En este sentido, se aprecia que el testigo de maíz País Tuxpeño presentó alta germinación y los tratamientos de 24 y 48 h de envejecimiento acelerado, baja germinación; de acuerdo a Delouche y Caldewel (1960) el porcentaje de germinación por sí solo no puede considerarse un adecuado índice de vigor, mientras que (Aristizábal y Álvarez, 2006) señalan que las semillas con germinación superior a $80 \%$ después del envejecimiento acelerado podrían ser clasificados como de alto vigor, entre $60-80 \%$ como vigor medio, y menores de $60 \%$ como de bajo vigor.
Germination, growth and development of maize seedlings was conducted in greenhouse, acceleratedly aged maize seeds were placed in plastic trays of $0.242 \mathrm{~m}^{2}$ with bovine manure as substrate which contained 2.24, 0.31 and $0.47 \%$ of N, P, K respectively. The germination and development variables were: initial seed weight (ISW), germination percentage (GP), average number of days to total germination (DTG), seedling height $(\mathrm{SH})$, total fresh weight (TFW), total dry weight (TDW), total leaf area (TLA), fresh and dry root and shoot weight (RFW, SFW, RDW, and SDW) respectively and shoot: root ratio (S: R). The analysis of the evaluated variables and Tukey means comparison test $(p<0.05)$ were performed using the Statistica Six Sigma software.

The initial weight of País Tuxpeño, X'nuuknal and Sinaloa showed significant differences $(p<0.05)$. The highest value of $8.5 \mathrm{~g}$ was observed in the Sinaloa maize while País Tuxpeño and X'nuuknal showed lower values of 7.1 and $6.9 \mathrm{~g}$ Figure 1.

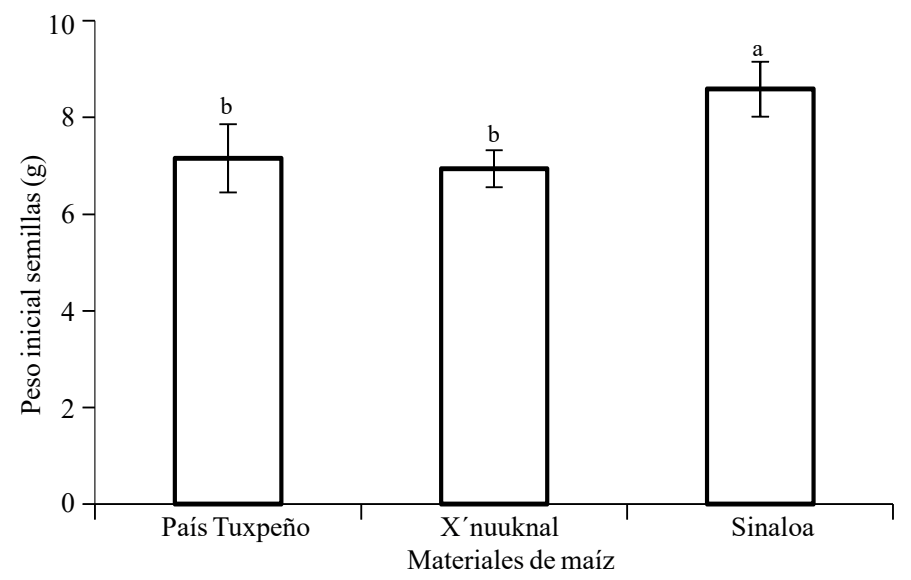

Figura 1. Peso inicial de semillas de maíz antes de su envejecimiento acelerado. Medias con las mismas literales son estadísticamente iguales.

Figure 1. Initial weight of maize seed before accelerated aging. Means with the same superscript are statistically equal.

The analysis of variables by effect of the application of accelerated aging according to the maize materials factor showed significant differences while the effect of accelerated aging times and the interaction showed significant differences only in germination percentage, this trend has been reported Salazar et al. (2006) who reported that maize seed quality is directly related to the increase of the accelerated aging time, decreasing the germination percentage thereof. 
Al analizar el factor tiempo Figura 2 A se encontraron diferencias significativas en el PG. Laprueba Tukey $(p<0.05)$ mostró que el testigo 0 h obtuvo el mayor PG $81 \%$ con respecto a los tiempos de 24 y $48 \mathrm{~h}$ de envejecimiento 71 y $70 \%$, fueron estadísticamente iguales pero por abajo del PG $80 \%$ requerido para producir germinados. Para la interacción material por tiempo Figura $2 \mathrm{~B}$ se observaron comportamientos diferentes en cuanto a la pérdida de la germinación con respecto al tiempo de envejecimiento acelerado en cada tipo maíz, mostrando el País Tuxpeño los mejores PG sin presentar diferencias estadísticas en los tres tiempos, mientras que el Sinaloa presentó los resultados más bajos $(p<0.05)$.

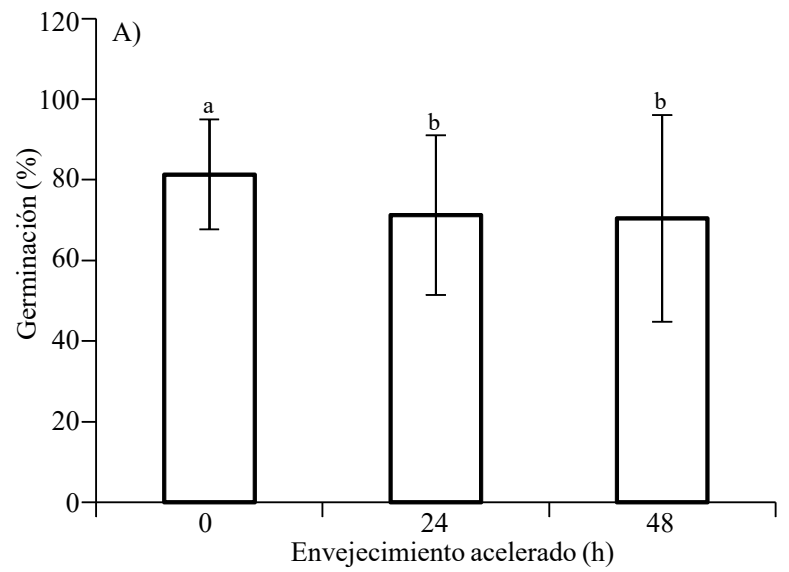

In this regard, the País Tuxpeño maize check showed high germination and the 24 and $48 \mathrm{~h}$ of accelerated aging treatments showed low germination; according to Delouche and Caldewel(1960) the germination percentage alone cannot be considered an adequate vigor index while Aristizábal and Alvarez, 2006 indicate that seeds over $80 \%$ germination after accelerated aging could be classified as high vigor, from 60 $80 \%$ average vigor, and under $60 \%$ as low vigor.

By analyzing the time factor in Figure 2A significant differences were found in the GP. The Tukey test $(p<0.05)$ showed that the 0 h check had the highest GPof $81 \%$ compared



Figura 2.A) efecto de los tres tiempos de envejecimiento acelerado; y B) interacción maíz y tiempo de envejecimiento acelerado sobre el porcentaje de germinación de País Tuxpeño, X'nuuknal y Sinaloa. Medias con las mismas literales son estadísticamente iguales.

Figure 2. A) Effect of the three accelerated aging times; and B) interaction maize and accelerated aging time on the germination percentage of País Tuxpeño, X'nuuknal and Sinaloa. Means with the same superscripts are statistically equal.

Entre los cultivares de maíz País Tuxpeño, X'nuuknal y Sinaloa se aprecian diferencias significativas en el número medio de días a germinación total, porcentaje de germinación, altura planta, peso fresco total y peso seco total $(p<0.05)$. De acuerdo a Aristazábal y Álvarez (2006) estas respuestas se deben a la composición genética particular de cada uno de los cultivares Cuadro 1. to the 24 and $48 \mathrm{~h}$ aging times with 71 and $70 \%$, which were statistically equal but below the $80 \%$ GP required to produce sprouts. For time by material interaction in Figure 2B different behaviors were observed for the loss of germination over accelerated aging time in each maize type, País Tuxpeño showing the best GP without statistical differences in the three times, while the Sinaloa showed the lowest scores $(p<0.05)$.

Cuadro 1. Número medio de días a germinación total NMDG, porcentaje de germinación PG, altura planta AP, peso fresco total PFT y peso seco total PST en maíz País Tuxpeño, X'nuuknal y Sinaloa sometidos a tres tiempos de envejecimiento 0, 24 y $48 \mathrm{~h}$. Medias con las mismas literales son estadísticamente iguales.

Table 1. Average number of days to total germination DTG, germination percentage GP, plant height PH, total fresh weight TFW and total dry weight TDW in País Tuxpeño, X'nuuknal and Sinaloa maize under three aging times 0, 24 and $48 \mathrm{~h}$. Means with the same superscripts are statistically equal.

\begin{tabular}{|c|c|c|c|c|c|}
\hline Cultivar & NMDG & $\mathrm{PG}$ & $\mathrm{AP}(\mathrm{cm})$ & $\operatorname{PFT}(\mathrm{g})$ & $\operatorname{PST}(g)$ \\
\hline País Tuxpeño & $3.09 \mathrm{a}$ & $95.46 \mathrm{a}$ & $37.73 \mathrm{a}$ & $53.64 \mathrm{a}$ & $4.36 \mathrm{a}$ \\
\hline $\begin{array}{l}\text { X'nuuknaal } \\
\text { Sinaloa }\end{array}$ & $\begin{array}{ll}3.11 & b \\
3.48 & b\end{array}$ & $\begin{array}{ll}74.44 & \mathrm{~b} \\
53.06 & \mathrm{c}\end{array}$ & $\begin{array}{l}27.06 \mathrm{~b} \\
40.02 \mathrm{a}\end{array}$ & $\begin{array}{ll}37.51 & \mathrm{a} \\
30.62 & \mathrm{~b}\end{array}$ & $\begin{array}{ll}3.16 & b \\
3.05 & b\end{array}$ \\
\hline
\end{tabular}


A pesar que no existió efecto significativo del factor simple tiempo de envejecimiento acelerado en el número medio de días a germinación total, resultado que coincide con Villaroel y Méndez (2007) se presentaron diferencias significativas entre materiales para la misma variable en País Tuxpeño y X'nuuknaal. El PG entre materiales de maíz obtuvo diferencias significativas, el País Tuxpeño presentó el mayor porcentaje de germinación $95 \%$ y el Sinaloa con el más bajo $53 \%$. Es probable que las condiciones de envejecimiento con calor húmedo propiciaran un mal funcionamiento de los eventos metabólicos implicados en la germinación, lo que indicaría que la estimulación de brotes radiculares es un suceso físico promovido por la rehidratación de los tejidos seminales (Bewley y Black, 1994).

Aunque la altura no presentó diferencias significativas por el factor simple tiempo de envejecimiento acelerado, el factor materiales mostraron diferencias significativas, la mayor altura fue País Tuxpeño $37 \mathrm{~cm}$ y Sinaloa $40 \mathrm{~cm}$ lo que coincide con Laynez et al. (2007), reportaron mayor altura en plántulas provenientes de semillas de maíz de mediano y mayor peso.

El mejor valor del PFT se obtuvo con semillas de menor PIS en País Tuxpeño y X'nuuknaal 53 y $37 \mathrm{~g}$ a los 12 DDS. Según Müller et al. (2005) $1 \mathrm{~kg}$ de maíz produce $9 \mathrm{~kg}$ de PFT. Se calculó que $1 \mathrm{~kg}$ de maíz País Tuxpeño produce $8.5 \mathrm{~kg}$ de PFT, este mismo cultivar obtuvo el mayor PST, mientras que X'nuuknaal y Sinaloa fue más bajo, ambos sin presentar diferencias estadísticas significativas.

El área foliar total AFT reveló diferencias significativas $(p<0.05)$ entre materiales de maíz, el efecto de tiempos de envejecimiento acelerado y de la interacción de tiempos por materiales de maíz no fue significativo. El AFT de País Tuxpeño, X' nuuknal y Sinaloa fue $44.9,38.8$ y $25.5 \mathrm{~cm}^{2}$.

A pesar que el efecto de tiempos de envejecimiento acelerado y la interacción tiempos por materiales de maíz no obtuvo efectos significativos, las variables PFR, PFV, PFT, PSR, PSV y PST presentaron diferencias significativas $(p<0.05)$ únicamente entre materiales de maíz. El mayor valor de PFT correspondió a la mejor relación del V: R de País Tuxpeño y X'nuuknal, mientras que Sinaloa fue menor en ambos casos Figura 3A. El peso seco total no presentó diferencias significativas entre materiales de maíz, mientras que la relación V: R si presentó diferencias significativas entre los tres materiales. La mayor relación V: R fue $\mathrm{X}^{\prime}$ nuuknal 1.85, País Tuxpeño 1.33 y Sinaloa 0.70 Figura 3B.
Among the País Tuxpeño, X'nuuknal and Sinaloa maize cultivars significant differences were observed in the mean number of days to total germination, germination percentage, plant height, total fresh weight and total dry weight $(p<0.05)$. According to Aristazábal and Alvarez (2006) these responses are due to the particular genetic composition of each cultivar, Table 1.

Although there was no significant effect of accelerated aging time as simple factor in the average number of days to total germination, a result consistent with Villarroel and Méndez (2007) significant differences were found between materials for the same variable in País Tuxpeño and X'nuuknaal. The GP between maize materials obtained significant differences País Tuxpeño showed the highest germination percentage with $95 \%$ and Sinaloa the lowest with $53 \%$. It is likely that the aging conditions with moist heat cause malfunction of the metabolic events involved in germination, suggesting that stimulation of root sprouts is a physical event promoted by rehydrating the seminal tissues (Bewley and Black, 1994).

Although no significant differences were found in height by the simple factor of accelerated aging time, the material factor showed significant differences, the greatest height was in País Tuxpeño $37 \mathrm{~cm}$ and Sinaloa $40 \mathrm{~cm}$ which coincides with Laynez et al. (2007) who reported greater height on seedlings from maize seeds with medium and higher weight.

The best TFW value was obtained with seeds of lower ISW in País Tuxpeño and X'nuuknaal 53 and $37 \mathrm{~g}$ at12 days after planting (DAP). According to Müller et al. (2005) 1 $\mathrm{kg}$ of maize produces $9 \mathrm{~kg}$ of TFW. It was estimated that $1 \mathrm{~kg}$ of País Tuxpeño maize produces $8.5 \mathrm{~kg}$ of TFW, this same cultivar had the highest TDW while X'nuuknaal and Sinaloa were lower, both without significant statistical differences.

The total leaf area TLA revealed significant differences $(p<$ 0.05 ) between maize materials, the effect of accelerated aging times and the interaction of time by maize cultivars was not significant. The TLA of País Tuxpeño, X'nuuknal and Sinaloa was $44.9,38.8$ and $25.5 \mathrm{~cm}^{2}$.

Although the effect of accelerated aging time and the interaction time by maize materials obtained no significant effects, the RFW, SFW, TFW, RDW, SD 

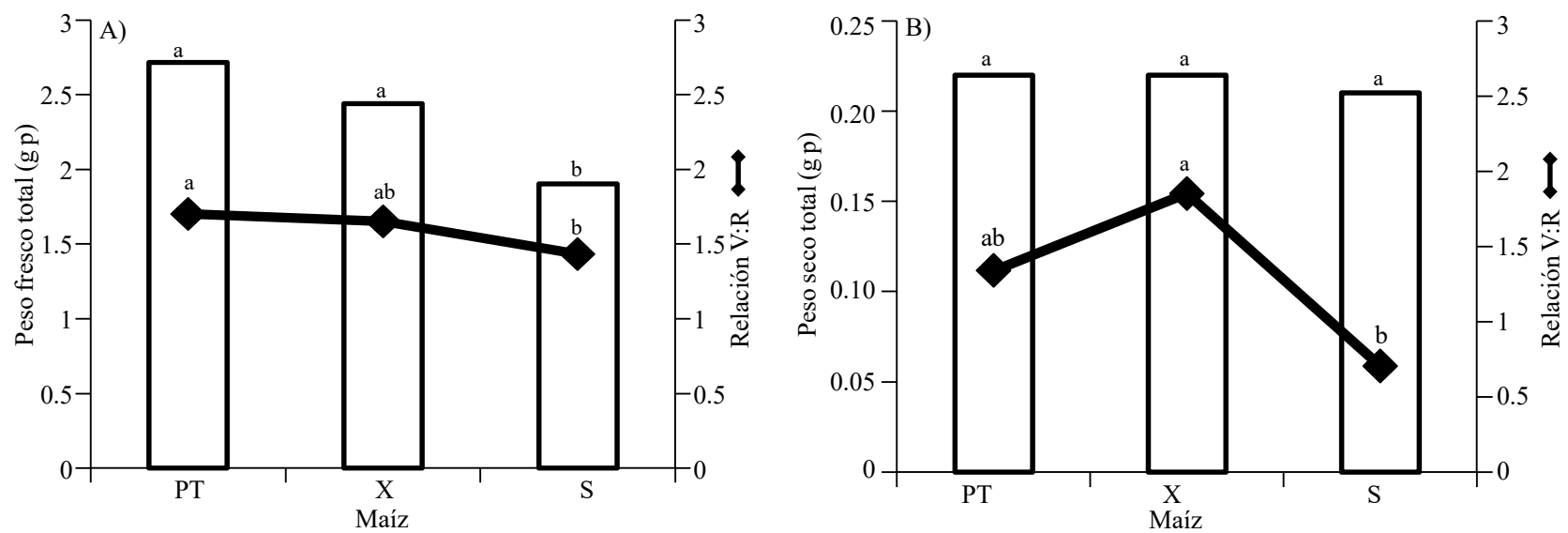

Figura 3. A) el peso fresco total y su relación vástago: raíz V:R; y B) el peso seco total y su relación vástago: raíz V: $R$, País Tuxpeño PT, X'nuuknal X y Sinaloa S, sometidos a envejecimiento acelerado. Medias con las mismas literales son estadísticamente iguales.

Figure 3. A) Total fresh weight and its shoot: root ratio S: R; and B) total dry weight and its shoot: root ratio S: R, País Tuxpeño PT, X'nuuknal $X$ and Sinaloa S, under accelerated aging. Means with the same superscript are statistically equal.

De los tres materiales de maíz envejecidos aceleradamente el País Tuxpeño conservólamejor capacidad de desempeñoensu viabilidad, crecimiento, desarrollo de plántulas y producción de peso fresco y seco total, su semilla fue capaz de resistir la exposición al deterioro durante 24 y $48 \mathrm{~h}$, mientras que los cultivares X'nuuknal y Sinaloa no conservaron su capacidad de desempeño y sus semillas fueron menos resistente a la exposición al deterioro, lo que permitió discriminar ambas semillas y precisar que el maíz País Tuxpeño conservó la calidad requerida para producirgeminados para forraje verde.

\section{Literatura citada}

Aristizábal, L. M. y Álvarez, L. P. 2006. Los efectos del nivel de vigor de la semilla pueden persistir e influenciar el crecimiento de la planta, la uniformidad de la plantación y la productividad. Agronomía. 14(1):17-24.

Barros, T. S. and Filho, J. M. 2003. Accelerated aging of melon seeds. Scientia Agrícola. 60(1):77-82.

Bewley, J. D. and Black, M. 1994. Seeds: physiology of development and germination. $2^{\text {ed }}$. Plenum Press, New York. 445 p.

Delouche, J. C. and Caldwell, P. W. 1960. Seed vigor and vigor tests. Proceedings of the Association of Official Seed Analysts. 50(1):136-140.

Durán, H. D.; Gutiérrez, H. G.; Arellano, V. J.; García, R. E. y Virgen, V. J. 2011. Caracterización molecular y germinación de semillas de maíces criollos azules con envejecimiento acelerado.Agron. Mesoam. 22(1):11-20.

Flores, H. A. 2004. Introducción a la tecnología de las semillas. Universidad Autónoma de Chapingo (UACH). Primera Edición, Chapingo-Estado de México. 61-76 pp.
$\mathrm{W}$ and TDW variables differed significantly $(p<0.05)$ only between maize cultivars. The greatest TFW value corresponded to the best $\mathrm{S}$ : $\mathrm{R}$ ratio of País Tuxpeño and $X$ 'nuuknal while Sinaloa was lower in both cases, Figure $3 \mathrm{~A}$. The total dry weight showed no significant differences between maize cultivars, while the $\mathrm{S}$ : $\mathrm{R}$ ratio did show significant differences between the three materials. The highest S: R ratio was X'nuuknal 1.85, País Tuxpeño 1.33 and Sinaloa 0.70, Figure 3B.

From the three maize materials under accelerated aging, País Tuxpeño retained the best performance capacity in viability, growth, seedling development and total fresh and dry weight production, its seed was able to withstand exposure to deterioration for 24 and $48 \mathrm{~h}$ while $\mathrm{X}$ 'nuuknal and Sinaloa cultivars did not keep their performance capacity and their seeds were less resistant when exposed to deterioration, allowing discrimination of both seeds and the indication that the País Tuxpeño maize retained the quality required to produce sprouts for green forage.

\section{End of the English version}

Laynez, G.; Méndez, N. y Mays, T. 2007. Crecimiento de plántulas a partir de tres tamaños de semilla de dos cultivares de maíz (Zea mays L.), sembrados en arena y regados con tres soluciones somáticas de sacarosa. IDESIA. 25(1):21-36. 
McDonald, M. B. 1999. Seed deterioration: physiology, repair, and assessment. Seed Sci. Technol. 27:177-237.

Müller, L.; Manfron, P.; Santos, O.; Medeiros, S.; Haut, V.; Dourado, D.; Binotto, E. y Bandeira, A. 2005. Producción y composición bromatológica de forraje hidropónico de maíz (Zea mays L.) con diferentes densidades de siembra y días de cosecha. Zootecnia Tropical. 23(2):105-119.

Salazar, P.; Trejo,A. y Hernández, L. M. 2006. Pruebas de envejecimiento acelerado en semillas de maíz (Zea mays L.) de diferentes bases genéticas. Rev. Unellez Cienc. Tecnol. 24:63-69.
Vashisth, A. 2009. Germination characteristics of seeds of maize (Zea mays L.) exposed to magnetic fields under accelerated ageing conditions. J. Agric. Physics. 9:55-58.

Villaroel, N. y Méndez, N. 2007. Calidad de semilla de nueve lotes de diferentes cultivares de maíz (Zea mays L.) afectada por el envejecimiento acelerado. Revista de la Facultad deAgronomía de La Universidad del Zulia. 24(1):89-94.

Vitoria, H. 2007 Relación de la calidad fisiológica de semillas de maíz con $\mathrm{pH}$ y conductividad eléctrica. Revista de la Facultad de Ciencias Agrarias. 39(2):91-100. 